\title{
SENGKETA WARISAN PERUSAHAAN PERORANGAN BERUBAH MENJADI PERUSAHAAN BERBADAN HUKUM*
}

\author{
Daniel Kuntjoro Budiman \\ Fakultas Hukum, Universitas Surabaya, \\ J1. Tenggilis Mejoyo, Kel. Kali Rungkut, Kec. Rungkut, Kota Surabaya, Jawa Timur 60293 \\ e-mail: danielkuntjoro17@gmail.com
}

\begin{abstract}
There is a circumstance where some children control an individual company owned by a parent and converted the company into a limited liability company with a loss to the rights of other heirs. The research aims to find on whether a parent's company is justified or not has been upgraded to a legal entity ignoring other heirs. By using a normative juridical approach, the study is conducted to emphasize the actual facts and analyzed it with applicable regulations. The result shows that it cannot be justified that a limited liability company is established from finances originating of a parent-owned company, since it violates the legitimacy of other heirs' rights.
\end{abstract}

Keywords: Parent' Company; Limited Company; Heir; Absolute Rights.

\begin{abstract}
Abstrak
Keadaan dimana sebagian anak menguasai perusahaan perorangan milik orang tua diubah menjadi badan hukum perseroan terbatas dengan merugikan hak ahli waris lainnya. Penelitian bertujuan mencari tahu dapat dibenarkan atau tidaknya perusahaan orang tua ditingkatkan menjadi suatu badan hukum mengabaikan ahli waris lainnya. Penelitian dilakukan dengan pendekatan yuridis normatif yaitu meneliti keadaan fakta sebenarnya lalu dianalisis dengan peraturan yang berlaku. Hasil penelitian menunjukkan bahwa tidak dapat dibenarkan jika memang bisa dibuktikan perseroan terbatas didirikan dari keuangan yang berasal dari perusahaan milik orang tua, dan melanggar legitime portie ahli waris lainnya.
\end{abstract}

Kata Kunci: Perusahaan Orang Tua; Mendirikan; Perseroan Terbatas; Mengabaikan; Ahli Waris; Hak Mutlak.

\footnotetext{
* Naskah diterima: 4 Agustus 2019, direvisi: 18 Januari 2020, disetujui untuk terbit: 26 Maret 2019 Doi: $10.3376 /$ jch.v5i2.188
} 
Daniel Kuntjoro Budiman: Sengketa Warisan Perusahaan Perorangan Berubah Menjadi...

\section{PENDAHULUAN}

Pengaturan Hukum Waris bertujuan untuk mengatur pelaksanaan beralihnya harta kekayaan atau warisan kepada ahli waris seadil-adilnya. Pembagian warisan sering menjadi pemicu konflik, sehingga diaturnya Hukum Waris dapat memberikan penyelesaian konflik pewarisan dalam keluarga. Fokus dari Hukum Waris adalah keluarga, dimana harus ada hubungan darah diantara pewaris dan ahli waris, kecuali untuk suami atau isteri dari pewaris yang masih terikat dalam perkawinan. (Kusumawati, 2011)

$$
\text { Survei yang dilakukan }
$$

Pricewaterhouse Cooper (yang selanjutnya disebut "PwC"), perusahaan audit asal Amerika Serikat, di tahun 2014, menyatakan bahwa Bisnis Keluarga Indonesia, mengenai bisnis keluarga di Indonesia mempunyai hasil lebih dari $95 \%$ perusahaan di Indonesia merupakan bisnis keluarga. PwC mendefinisikan bisnis keluarga sebagai perusahaan yang mayoritas hak suaranya berada di tangan pendiri atau orang yang mengakuisisi perusahaan, misalnya pasangan, orang tua, anak atau ahli waris. Hal ini berarti hampir semua perusahaan di Indonesia dimiliki oleh keluarga, mulai dari bidang manufaktur, transportasi, konstruksi, jasa dan lain-lain. Bisnis keluarga memang sangat diminati di Indonesia karena memilih bisnis keluarga tujuan utamanya adalah memastikan masa depan jangka panjang perusahaan. Selain itu tujuan lainnya meningkatkan profitabilitas, lebih inovatif, berkontribusi pada masyarakat, memberikan peninggalan atau warisan, dan menciptakan peluang kerja bagi anggota keluarga. Dimana keterlibatan generasi penerus dalam bisnis keluarga Indonesia sebesar 60\%, hal ini lebih tinggi dari rata-rata global yang hanya $55 \%$ saja. Namun terdapat fakta bahwa usia perusahaan sebagian besar berkisar 20-49 tahun, dan hampir selalu berakhir pada generasi ketiga. (PricewaterhouseCoopers, 2014)

Sengketa warisan yang akan dibahas adalah sengketa warisan perusahaan keluarga kopi bubuk Kapal Api. Pada mulanya Go Soe Loet sebagai pendiri kopi bubuk Kapal Api memiliki perusahaan bernama Hap Hoo Tjan, dimana ia telah bekerja keras dibantu oleh anak-anaknya merintis usaha hingga usahanya berkembang pesat. Harta warisan Go Soe Loet berbentuk perusahaan perorangan namun dijadikan perseroan terbatas oleh sebagian anak-anaknya, yaitu Indra Boedijono dan Soedomo Mergonoto, tanpa melibatkan saudara-saudara kandungnya yang lain. Di persidangan terbukti secara faktual bahwa pada awalnya pabrik kopi didirikan oleh orang tua, modal saham perseroan terbatas berasal sepenuhnya dari Go Soe Loet dan isterinya.

Terdapat kesenjangan antara hukum dan fakta bahwa perubahan perusahaan perorangan kopi bubuk Kapal Api semula Hap Hoo Tjan dimiliki pewaris kemudian ditingkatkan menjadi badan hukum oleh Indra Boedijono dan Soedomo Mergonoto. Seharusnya tidak hanya dimiliki oleh Indra, Soedomo dan Singgih saja, tetapi juga menyertakan saudara-saudaranya yaitu ahli-ahli waris lainnya. Gugatan diajukan saudara-saudara yang merasa 
dirugikan kepada Indra Boedijono, Soedomo Mergonoto dan Singgih Gunawan. Pada tingkat kasasi upaya saudara-saudara yang merasa dirugikan gagal dengan menyatakan gugatan tidak dapat diterima, sehingga penggugat tidak mewarisi harta warisan berupa perusahaan yang berasal dan dirintis oleh orang tuanya.

Berdasarkan permasalahan tersebut tujuan dilakukan penelitian ini adalah mengetahui sengketa warisan perusahaan yang semula perorangan berubah menjadi berbadan hukum dapat dibenarkan atau tidak. Dimana perusahaan perorangan yang merupakan warisan Go Soe Loet dan Po Guan Cuan diubah menjadi badan hukum PT Santos Jaya Abadi dimiliki oleh Indra Boedijono, Soedomo Mergonoto dan Singgih Gunawan. Dipicu banyaknya perusahaan keluarga di Indonesia, kasus ini menjadi pelajaran tersendiri bagi masyarakat supaya lebih sadar pentingnya mengerti hukum waris, setidak-tidaknya menghindarkan kejadian serupa terjadi lagi. (R. Santoso Pudjosubroto, 1964)

\section{METODE PENELITIAN}

Metode penelitian yang digunakan adalah yuridis normatif yang mana berdasarkan fakta dianalisis menggunakan literatur dan peraturan perundangundangan yang didapat dari studi kepustakaan. Hal ini dilakukan analisisnya menggunakan pendekatan deduktifinduktif. Pendekatan masalahnya menggunakan pendekatan Statute Approach dan Conceptual Approach. Statute Approach adalah pendekatan yang didasarkan pada ketentuan hukum positif yang berlaku di Indonesia, dalam hal ini Burgerlijk Wetboek (untuk selanjutnya disebut "BW"). Sedangkan Conceptual Approach adalah pendekatan yang didasarkan dan dikaitkan dengan pendapat para sarjana yang berkaitan dengan permasalahan tersebut. Bahan dan sumber hukum dilakukan studi pustaka diantaranya adalah Undang-Undang Dasar Negara Republik Indonesia Tahun 1945, Kitab Undang-Undang Hukum Perdata, Undang-Undang Nomor 40 Tahun 2007 tentang Perseroan Terbatas, Putusan Perkara Nomor 245/Pdt.G/2013/PN.Sby juncto 565/Pdt/2013/PT.Sby juncto 1600K/PDT/2014, selain itu juga terdapat bahan hukum lainnya yaitu literaturliteratur yang berkaitan dengan masalah yang dibahas.

\section{HASIL DAN PEMBAHASAN}

Proses Pewarisan Go Soe Loet dan Po Guan Cuan yaitu orang keturunan Timur Asing Tionghoa, tunduk pada ketentuan Pasal 131 IS jo. Staatsblad 1917 Nomor 12 jo. Staatsblad 1924 Nomor 557 tentang Penundukkan Diri terhadap Hukum Eropa. Berdasarkan Pasal 119 BW, sejak saat dilangsungkannya perkawinan, maka menurut hukum terjadi harta bersama menyeluruh antara suami-isteri. (Afandi, 1986)

Pewarisan terjadi sebagaimana Pasal 830 BW adalah terjadi karena kematian, ahli waris harus ada pada waktu meninggalnya si peninggal warisan dan ada sejumlah harta kekayaan yang ditinggalkan (Kamilah \& Aridhayandi, 2015). Meninggalnya Go Soe Loet dan Po Guan Cuan, adanya 7 orang ahli waris 
Daniel Kuntjoro Budiman: Sengketa Warisan Perusahaan Perorangan Berubah Menjadi...

waktu meninggal dan ada sejumlah harta kekayaan yang ditinggalkan, yaitu perusahaan pembuatan kopi bubuk dengan merek Kapal Api yang ditinggalkan Go Soe Loet dan Po Guan Cuan.

Go Soe Loet yang meninggal pada 12 Juli 1993 meninggalkan ahli waris yaitu Po Guan Cuan, dan anak-anaknya yaitu Soetikno Gunawan, $\mathrm{Wu}$ Yuee, Indra Boedijono, Soedomo Mergonoto, Singgih Gunawan, Lenny Setyawati, dan Wiwik Sundari Guntur. Sedangkan Po Guan Cuan meninggal pada tanggal 14 Oktober 2002, ahli warisnya adalah Soetikno Gunawan, Lenny Setyawati dan Wiwik Sundari Guntur. Hal ini berdasarkan Pasal 833 ayat $1 \mathrm{BW}$, ahli waris karena hukum memiliki barang, hak-hak dan segala piutang dari orang yang meninggal dunia. Le Mort Saisit Le Vit, yang telah meninggal dunia meluangkan tempat bagi yang masih ada. Dalam Pasal 852 KUH Perdata, telah ditentukan bahwa orang yang pertama kali dipanggil undang-undang untuk menerima warisan adalah anak-anak dan suami atau isteri. Bagian yang diterima oleh mereka adalah sama besar antara satu dengan yang lainnya (Wahyu Setiadi \& Sumarto, 2014). Pengertian ahli waris yang bersumber dari prinsip menurut Pasal 832 KUH Perdata adalah setiap orang yang berhak atas harta peninggalan pewaris dan berkewajiban menyelesaikan hutang-hutangnya. Hak dan kewajiban tersebut timbul setelah pewaris meninggal dunia. Hak ini didasarkan pada hubungan perkawinan, hubungan darah dan surat wasiat. Ketentuan dalam Pasal 833 ayat (1) BW menyatakan, bahwa sekalian ahli waris dengan sendirinya karena hukum memperoleh hak milik atas semua harta kekayaan orang yang meninggal dunia (pewaris) (Wattimena, 2017).

Pewarisan Go Soe Loet adalah secara ab-intestato, karena sewaktu hidup tidak menentukan sendiri tentang apa yang akan terjadi terhadap harta kekayaannya sehingga undang-undang mengatur dalam Pasal 874 BW bahwa kepunyaan ahli waris, sekadar tidak ada ketetapan dalam suatu surat wasiat. Berdasarkan Pasal 126 BW, dimana harta bersama bubar demi hukum karena kematian. Berdasarkan pasal 128 BW dikatakan bubarnya harta bersama, kekayaan bersama mereka dibagi dua antara suami dan isteri, atau antara para ahli waris mereka, tanpa mempersoalkan dan pihak mana asal barang-barang itu hanyalah setengah bagian dari seluruh harta bersama (Satrio, 1998). Ahli waris dari Go Soe Loet adalah Po Guan Cuan isterinya, Soetikno Gunawan, Wu Yuee, Indra Boedijono, Soedomo Mergonoto, Singgih Gunawan, Lenny Setyawati, dan Wiwik Sundari Guntur. Bagian masing-masing ahli waris adalah sama rata 8 orang, yaitu 7 anak dan 1 janda Po Guan Cuan, sehingga masingmasing ahli waris mendapat bagian 1/8 bagian dari harta warisan Go Soe Loet, yaitu $1 / 16$ bagian.

Sedangkan Po Guan Cuan sebelum meninggal dunia, telah meninggalkan wasiat berarti melangsungkan pewarisan secara testamentair. (Emeliana Krisnawati, 2006) Wasiat berisi hibah wasiat berdasarkan pasal 957 BW. Wasiat yang dibuatnya memenuhi syarat formal. Syarat formal, dibuat di hadapan notaris dan 
dihadiri 2 orang saksi. Saksi tidak boleh ahli waris, maupun keluarga sedarah dan keluarga berdasarkan semenda sampai dengan derajat ke-6. Selain itu juga harus memenuhi syarat yaitu sudah dewasa, penduduk Indonesia dan paham akan Bahasa yang digunakan dalam testamen (Tamakiran, 1987). Menghadirkan saksisaksi yaitu ibu mertua dari anaknya, Indra Boedijono dan adik ipar Indra Boedijono. Menunjukkan bahwa pembuatan wasiat menghadirkan saksi-saksi yang sepihak, sehingga sangat mungkin bahwa wasiat dibuat dengan keadaan tipu muslihat. Berdasarkan Pasal 893 BW, suatu testamen adalah batal jika dibuat dengan paksa, tipu, dan muslihat. Namun wasiat tidak memenuhi syarat materiel, yaitu wasiat haruslah mengenai barang-barang dimiliki si peninggal waris berdasarkan Pasal 966 BW. Apabila pewaris menghibahwasiatkan sesuatu benda tertentu yang dipunyai orang lain maka hibah-wasiat batal.

Hibah wasiat adalah perbuatan hukum pewaris sebelum ia meninggal dunia. Dimana diketahui yang dimaksud dengan perbuatan hukum adalah:

"Perbuatan dengan tujuan untuk pernyataan kemauan yang terkandung di dalamnya, menciptakan suatu hak bagi seseorang atau merubah suatu hak bagi seseorang atau merubah sesuatu hak yang telah ada atau mengakhirinya". (Boty, 2017)

Sehingga berdasarkan pembahasan diatas dihubungkan dengan hak perdata subjek hukum (manusia dan badan hukum) untuk melakukan suatu perbuatan hukum, perjanjian dan penetapan atas apa yang mereka inginkan atau kehendaki, merupakan tindakan yang dapat menjamin perbuatan, perjanjian dan penetapan tersebut jika dituangkan dalam akta otentik yang dibuat oleh Notaris, dan hak perdata mereka pun menjadi lebih terjamin oleh hukum dan tidak dapat diganggu gugat oleh pihak lain sepanjang undang-undang tidak melarangnya. (Boty, 2017)

Wasiat dibuatnya yang membagikan seluruh dari harta bersama tidak dapat dibenarkan. Berdasarkan Pasal 119 BW sejak dilangsungkannya perkawinan, maka menurut hukum terjadi harta bersama menyeluruh antar suami isteri, sejauh tentang hal itu tidak diadakan ketentuanketentuan lain dalam perjanjian perkawinan. Berdasarkan Pasal 126 BW, harta bersama bubar demi hukum salah satunya adalah karena kematian. Maka berdasarkan Pasal 128 BW, setelah bubarnya harta bersama, kekayaan bersama mereka dibagi dua antara suami dan isteri, tanpa mempersoalkan dari pihak mana asal barang-barang itu. Harta warisan yang dimiliki dan dapat diwariskan oleh Po Guan Cuan hanyalah setengah bagian dari seluruh harta bersama ditambah dengan bagiannya sebagai ahli waris atas meninggalnya Go Soe Loet, suaminya. Harta warisan Po Guan Cuan adalah $1 / 2$ harta bersama ditambah 1/16 bagian harta bersama, yaitu 9/16 bagian harta bersama.

Pengaturan dalam hukum waris barat terdapat dua unsur penting:

a. Unsur individual (menyangkut diri pribadi seseorang). Pada prinsipnya seseorang pemilik atas suatu benda mempunyai kebebasan yang seluas- 
Daniel Kuntjoro Budiman: Sengketa Warisan Perusahaan Perorangan Berubah Menjadi...

luasnya sebagai individu untuk berbuat apa saja atas benda yang dimilikinya termasuk harta kekayaannya menurut kehendaknya.

b. Unsur sosial (menyangkut kepentingan bersama). Perbuatan yang dilakukan pemilik harta kekayaan sebagaimana dijelaskan dalam unsur individual dapat mengakibatkan kerugian pada ahli waris sehingga undang-undang memberikan pembatasan-pembatasan terhadap kebebasan pewaris demi kepentingan ahli waris. (Mohammad Yasir Fauzi, 2016)

Hibah wasiat ada di dalam rumusan pasal 957 BW, dikatakan bahwa hibah wasiat adalah suatu penetapan yang khusus, dengan mana pewaris memberikan wasiat kepada seorang atau lebih memberikan beberapa barang atau harta kekayaannya dari jenis tertentu, seperti misalnya memberikan barang bergerak atau semua barang tidak bergerak atau memberikan hak pakai hasil atau seluruh atau sebagian harta peninggalannya (Pratama, Syaifuddin, \& Elmadiantini, 2015). Wasiat yang dibuat oleh Po Guan Cuan isi pada pokoknya adalah membagikan saham-saham dari perusahaan yang memproduksi kopi dengan merek Kapal Api yaitu PT Santos Jaya Abadi harus dibagi diantara anakanaknya dengan komposisi Indra Boedijono sebagai pemegang 30\% saham, Soedomo Mergonoto sebagai pemegang $30 \%$ saham, Singgih Gunawan sebagai pemegang 30\% saham, Lenny Setyawati sebagai pemegang 5\% saham, dan Wiwik Sundari Guntur sebagai pemegang 5\% pemegang saham ternyata juga bertentangan dengan hukum. Ternyata Go Tek Yok atau Soetikno Gunawan dan Wu Yuee tidak dimasukkan dalam wasiat tersebut.

Meskipun Po Guan Cuan melangsungkan pewarisan secara testamentair, namun ahli-ahli warisnya memiliki legitime portie, yaitu hak yang diberikan undang-undang kepada ahli waris tertentu karena hubungannya demikian dekat dengan pewaris sehingga hak mereka atas harta warisan perlu dilindungi undang-undang (Prodjodikoro, 1986). Menurut Pasal 913 BW, Legitime Portie adalah sesuatu bagian dari harta peninggalan yang harus diberikan kepada waris, garis lurus menurut ketentuan undang-undang terhadap mana si yang meninggal tak diperbolehkan menetapkan sesuatu baik selaku pemberian antara yang masih hidup, maupun selaku wasiat (Pangemanan, 2016). Karena dalam pewarisannya ada wasiat atau testamen yang bisa dilaksanakan, maka untuk memastikan pemberian tersebut menyinggung/melanggar hak mutlak para ahli waris legitimaris atau tidak, perlu mencari besarnya hak mutlak para ahli legitimaris tersebut berdasarkan Pasal 914 BW.

Pasal 834 BW mengatur, bahwa ahli waris berhak mengajukan gugatan untuk memperoleh warisannya terhadap semua orang yang memegang bezit atas seluruh atau sebagian warisan itu dengan alas hak ataupun tanpa alas hak, demikian pula terhadap mereka yang dengan licik telah menghentikan bezit-nya Dia oleh mengajukan gugatan itu untuk seluruh 
warisan bila ia adalah satu-satunya ahli waris atau hanya untuk sebagian bila ada ahli waris lain, Gugatan itu bertujuan menuntut supaya diserahkan apa saja yang dengan alas hak apapun dalam warisan itu beserta segala penghasilan, pendapatan dan ganti rugi, menurut peraturan yang termasuk dalam Bab III buku ini mengenai penuntutan kembali hak milik (Dewi \& Purwanti, 2014).

Hap Hoo Tjan merupakan cikal bakal dari pendirian PT Santos Jaya Abadi berdasarkan fakta-fakta yang dikemukakan di persidangan bahwa:

1. Kelima anak, yaitu Indra Boedijono, Soedomo Mergonoto, Singgih Gunawan, Lenny Setyawati dan Wiwik Sundari Guntur tidak dapat bersekolah karena sekolah warga keturunan Tionghoa ditutup oleh pemerintah sehingga mereka membantu pembuatan dan perdagangan kopi usaha orang tuanya dengan pembagian tugas anak laki membantu tenaga pemasaran dan anak perempuan bekerja membantu penimbangan dan pembungkusan. Setidaknya hingga meninggalnya Go Soe Loet pada tahun 1993, kelima anak masih mengelola perusahaan PT Santos Jaya Abadi. Hal ini menandakan bahwa PT Santos Jaya Abadi masih perusahaan yang sama dikelola oleh keluarga Go Soe Loet.

2. Hasil kerja Hap Hoo TJan membuahkan hasil pada tahun 1972 Go Soe Loet membeli aset tanah di Kenjeran seluas $2000 \mathrm{~m}^{2}$ yang didaftarkan atas nama Indra
Boedijono karena sebagai satusatunya anggota keluarga yang telah memiliki status WNI, sesungguhnya berasal dari uang dari Go Soe Loet telah terbukti di persidangan. Di atas tanah itu didirikan pabrik yang memproduksi kopi dengan merek Kapal Api. Pabriknya bernama Santos Jaya oleh Indra Boedijono dan Soedomo Mergonoto. inilah yang menjadi pabrik pertama, awal mula dan cikal bakal didirikannya PT Santos jaya Abadi. telah melakukan perbuatan melanggar hukum pasal 1365 karena menggunakan uang orang tua untuk kepentingan diri mereka sendiri, dengan mengabaikan kepentingan ahli-ahli waris lainnya. Harta warisan meliputi seluruh harta benda serta hak dan kewajiban pewaris dalam lapangan hokum harta kekayaan yang dapat dinilai dengan uang (M. Suparman, 2005). Warisan meliputi seluruh harta benda beserta hak-hak dan kewajiban-kewajiban pewaris dalam lapangan hukum harta kekayaan yang dapat dinilai dengan uang (Isnaini, 2014).

3. Pabrik Santos Jaya di tanah Kenjeran juga memproduksi kopi dengan merek Kapal Api yang telah terdaftar oleh Go Soe Loet, dan tidak pernah sekalipun Go Soe Loet memindahkan atau mengalihkan hak atas merek kapal api kepada siapapun. Saat pendirian PT Santos Jaya Abadi masih memproduksi kopi dengan merk kapal api yang masih terdaftar atas nama Go Soe Loet. dari perusahaan masih perorangan Hap Hoo Tjan, menjadi 
Daniel Kuntjoro Budiman: Sengketa Warisan Perusahaan Perorangan Berubah Menjadi...

PT Santos Jaya Abadi, hingga sekarang masih memproduksi merek kapal api. Baru pada tahun 1983, merek kapal api dimohonkan perpanjangan pendaftaran nomor 175972 dengan atas nama PT Santos Jaya Abadi.

4. Indra Boedijono juga tidak banyak membantu perusahaan setelah ia mendirikan pabrik santos jaya pada tahun 1973, ia pindah ke jakarta untuk memulai usahanya sendiri. posisinya digantikan oleh Soedomo Mergonoto sebagai tenaga pemasaran. Kemudian pabrik kopi di kenjeran semakin berkembang dan posisinya digantikan oleh Singgih Gunawan dibantu oleh tenaga pemasaran Soedomo Mergonoto dan seorang rekan. Tahun 1979, Indra Boedijono kembali ke Surabaya dan kembali lagi ke usaha perdagangan kopi keluarga dengan mengubah bentuk perusahaan keluarga dari perusahaan perorangan menjadi badan hukum.

5. PT Santos Jaya Coffee Company didirikan oleh Ahmad Rinvai Anwar sebesar 60 surat sero, Indra Boedijono 8 surat sero, Soedomo Mergonoto 8 surat sero, dan Julia Poernomo yang merupakan isteri Indra Boedijono, dengan 4 surat sero. Ternyata tidak lama Ahmad Rinvai Anwar mempertahankan sahamnya sehingga telah dilakukan pengesahan jual beli saham milik Ahmad Rinvai Anwar selaku penjual kepada Indra Boedijono, yang termuat dalam akte No. 25 tentang penjualan dan pemindahan tanggal 18 mei 1979 di hadapan notaris Rika You Soo Shin di Surabaya. Selanjutnya juga ditegaskan dalam akte tersebut peralihan saham Julia Poernomo kepada Soedomo Mergonoto sehingga dibuat dalam Akta No.7 tanggal 11 April 1994 dibuat di hadapan Notaris Rika You Soo Shin berita acara susunan pemegang saham PT Santos Jaya Abadi adalah:

a. Indra Boedijono 40 saham

b. Soedomo Mergonoto 19 saham

c. Singgih Gunawan 20 saham

d. Julia Poernomo 1 saham

Ahmad Rinvai Anwar seorang sarjana hukum yang merupakan pendiri dengan saham terbanyak PT Santos Jaya Coffee kurang dari setahun menjual seluruh sahamnya kepada Indra Boedijono. Juga Julia Poernomo yang kurang dari setahun juga menjual sebagian besar sahamnya kepada Soedomo Mergonoto hingga hanya memegang 1 (satu) lembar saham. Menunjukkan patut dicurigai Ahmad Rinvai Anwar dan Julia Poernomo tidak secara sungguh-sungguh sebagai pendiri PT Santos Jaya Abadi. Seakan telah di skenario pendirian PT Santos Jaya Abadi bukan berasal dari orang tuanya. PT Santos Jaya Abadi terus berkembang hingga saham pada dari tahun 1979, 1994, 2000, 2008 hingga 2010.

Berdasarkan wasiat yang dibuat oleh Po Guan Cuan yang isinya menjelaskan bahwa Go Soe Loet semasa hidupnya adalah pendiri dari perusahaan kopi dengan merek kapal api yaitu PT Santos 
Jaya Abadi membagi warisan sebesar $30 \%$ kepada Indra Boedijono, 30\% Soedomo Mergonoto, 30\% pada Singgih Gunawan, dan 5\% kepada Lenny Setyawati dan 5\% kepada Wiwik Sundari Guntur, diajukan gugatan oleh Lenny Setyawati dan Wiwik Sundari Guntur mendasarkan diri pada surat wasiat dan surat pernyataan yang dibuat oleh Po Guan Cuan bahwa sesungguhnya pemilik dari perusahaan PT Santos Jaya Abadi adalah milik orang tua, sehingga dapat diwariskan.

Pada saat itu, ibu mertua Indra Boedijono dan ipar Indra Boedijono turut hadir dalam dan menyaksikan peristiwa hukum pembuatan surat wasiat tersebut. kehadiran mereka membuktikan Indra Boedijono mengetahui dan memahami bahwa tujuan dari Po Guan Cuan adalah menyatakan keinginannya sehubungan dengan perusahaan PT Santos Jaya Abadi merupakan milik Po Guan Cuan dan Go Soe Loet sehingga dapat diwariskan. Selain itu kehadiran saksi-saksi hanya pada pihak Indra Boedijono dengan tidak menghadirkan saksi-saksi dari ahli waris yang lain sehingga ada kemungkinan wasiat dibuat oleh Po Guan Cuan dengan adanya tipu muslihat.

Gugatan diajukan dengan register perkara 245/Pdt.G/2013/PN.Sby dengan petitum menetapkan harta warisan peninggalan Go Soe Loet dan Po Guan Cuan adalah menjadi hak ahli waris dengan bagian masing-masing Indra boedijono, Soedomo Mergonoto, Singgih Gunawan, Lenny Setyawati, dan Wiwik Sundari Guntur sebesar 1/5 bagian dari seluruh saham yang telah ditempatkan dan disetor penuh dalam PT Santos Jaya Abadi; memerintahkan kepada Direksi PT Santos Jaya Abadi untuk membagi harta warisan peninggalan Go Soe Loet dan Po Guan Cuan setiap dan semuanya itu secara berkesesuaian penuh; memerintahkan kepada Direksi PT Santos Jaya Abadi untuk menyelenggarakan Rapat Umum Pemegang 7 Saham PT Santos Jaya Abadi dengan agenda perubahan susunan pemegang saham berdasarkan putusan Pengadilan Negeri Surabaya ini.

1. Eksepsi dari Indra Boedijono adalah

1) Gugatan tidak berdasarkan hukum

2) Gugatan para penggugat kurang pihak

3) Gugatan diajukan secara kabur

2. Eksepsi dari Soedomo Mergonoto

Tidak seluruh ahli waris Go Soe Loet dan Po Guan Cuan dijadikan pihak dalam perkara, karena memiliki 7 anak yaitu Soetikno Gunawan, Wu Yuee, Indra Boedijono, Soedomo Mergonoto, Singgih Gunawan, Lenny Setyawati, dan Wiwik Sundari Guntur

3. Eksepsi Singgih Gunawan

a. Bahwa Tergugat III Singgih Gunawan mendukung sepenuhnya gugatan Para Penggugat;

b. Bahwa gugatan terhadap harta warisan Go Soe Loet dan Po Guan Cuan yaitu berupa saham-saham PT Santos Jaya Abadi yang didirikan berdasarkan hukum dan menurut peraturan perundangundangan yang berlaku di Indonesia berkedudukan di Sidoarjo, Jawa Timur; 
Daniel Kuntjoro Budiman: Sengketa Warisan Perusahaan Perorangan Berubah Menjadi...

c. Bahwa saham-saham PT Santos Jaya Abadi dimuat secara tegas dalam akta Pernyataan No.1 dan Akta Wasiat Nomor 2.

d. Bahwa menyatakan batal atau tidak saha Akta Pernyataan Nomor 1 dan Akta Wasiat Nomor 2 tanggal 1 Oktober 1994 yang dibuat dihadapan Rika You Soo Shin.

Hakim mendasari putusannya dengan pertimbangan bahwa Akta Pernyataan Nomor 1 tanggal 1 Oktober 1994 yang dibuat di hadapan Notaris Rika You Soo Shin, disebutkan Po Guan Cuan sebagai isteri Go Soe Loet yang mendirikan PT Santos Jaya Abadi. Berdasarkan permohonan merek kapal api tanggal 1 Juli 1962 atas nama Go Soe Loet pernah dan mengajukan pendaftaran merek kapal api. Berdasarkan profil perusahaan kapal api dan terjemahan resmi profil perusahaan Go Soe Loet merupakan ayah kandung dari para penggugat dan tergugat adalah pendiri dari group kapal api. Berdasarkan transkrip video yang dibuat oleh Soedomo Mergonoto yang menceritakan sejarah kopi kapal api yang pada pokoknya kapal api didirikan oleh ayahnya, Go Soe Loet, dan dulu pabrik kopi tersebut di jalan panggung Surabaya di pasar pabean, dan pengakuan dirinya kalau merek kopi kapal api yang mendaftarkan adalah Go Soe Loet. Transkrip Video Paulus Nugroho direktur PT Agel Langgeng anak perusahaan PT Kapal Api Group sekarang menjadi Direktur PT Santos Jaya Abadi menerangkan bahwa Go Soe Loet Founder dari Kapal Api cikal bakal dari PT Santos Jaya Abadi.
Surat yang dibuat Soedomo Mergonoto pada 5 November 2008 yang isinya berniat melakukan perubahan modal PT Santos Jaya Abadi demi melaksanakan amanat orang tua, yaitu berdasarkan wasiat maka $1.67 \%$ saham akan diberikan kepada Lenny Setyawati dan Wiwik Sundari. Selain itu pula surat yang dibuat Singgih Gunawan, tanggal 22 oktober 2008 yang isinya berniat kelebihan $1.67 \%$ sahamnya diberikan kepada Lenny Setyawati dan Wiwik sundari Guntur. Demi melaksanakan wasiat Po Guan Cuan. Berdasarkan keterangan para saksi Mukim, Saburo Gunawan, Liem Pik Hwa yang menerangkan bahwa Go Soe Loet dan Po Guan Cuan merupakan pendiri dari PT Santos Jaya Abadi yang memproduksi kopi dengan merek kapal api. Bahkan hingga Go Soe Loet meninggal masih dikelola oleh 4 anak kandung dari Go Soe Loet dan Po Guan Cuan, yaitu Soedomo Mergonoto, Singgung Gunawan, Lenny Setyawati dan Wiwik Sundari Guntur. Berdasarkan jawaban tergugat III, Singgih Gunawan, yang menerangkan bahwa gugatan adalah merupakan gugatan harta warisan orang tuanya.

Putusan tingkat Banding Putusan Nomor 565/PDT/2013/PT.Sby, tanggal 15 Januari 2014, dalam putusannya menyatakan Majelis Hakim Pengadilan Tinggi dapat menyetujui dan membenarkan pertimbangan Majelis Hakim tingkat pertama dalam pokok perkara yang mengabulkan gugatan Para Penggugat, karena telah memuat pertimbangan yang tepat dan benar semua keadaan serta alasan yang menjadi dasar dalam putusan dan pertimbangan- 
pertimbangan tersebut dianggap benar dan telah tercantum pula pada putusan tingkat banding.

Tidak terima terhadap putusan Judex Facti, Tergugat mengajukan Kasasi sebagaimana ternyata dalam Akta Permohonan Kasasi Nomor 245/Pdt.G/2013/PN.Sby., jo. Nomor 565/PDT/2013/PT.Sby. Dalam Kasasi, Mahkamah Agung berpendapat bahwa alasan-alasan Kasasi Para Pemohon Kasasi tentang Gugatan Kurang Pihak dapat Dibenarkan, Judex Facti telah salah menerapkan hukum dengan pertimbangan bahwa petitum yang isinya memerintahkan direksi PT Santos Jaya Abadi membagi harta warisan Go Soe Loet dan Po Guan Cuan dan memerintahkan direksi PT Santos Jaya Abadi menyelenggarakan Rapat Umum Pemegang Saham dengan agenda perubahan susunan pemegang saham berdasarkan Putusan Pengadilan Negeri Surabaya. Akan tetapi ternyata PT Santos Jaya Abadi tidak diikutsertakan sebagai pihak Tergugat, selain itu petitum memerintahkan kepada Para Pemegang Saham PT Santos Jaya Abadi untuk tunduk pada putusan, akan tetapi para Pemegang Saham lainnya tidak ikut sebagai pihak Tergugat dan Turut Tergugat dengan demikian apabila gugatan dikabulkan eksekusi tidak dapat dilaksanakan sehingga tidak dapat menyelesaikan perkara secara tuntas.

Saham PT Santos Jaya Abadi tidak dapat diwariskan seluruhnya oleh Go Soe Loet dan Po Guan Cuan. Saham yang dapat diwariskan hanya terbatas pada saham-saham yang dimiliki oleh Indra
Boedijono, Soedomo Mergonoto dan Singgih Gunawan. Karena PT Santos Jaya Abadi telah didirikan tunduk pada peraturan perundang-undangan yang berlaku tentang Perseroan Terbatas yaitu:

1. Kitab Undang-Undang Hukum Dagang.

2. Undang-Undang Nomor 1 Tahun 1995 tentang Perseroan Terbatas.

3. Undang-Undang Nomor 40 Tahun 2007 tentang Perseroan Terbatas

Sedangkan putusan Judex Facti hanya menggunakan Akta Pernyataan Nomor 1 Tahun 1994 dan Akta Wasiat Nomor 2 Tahun 1994 sebagai dasar utama mengabaikan bukti Akta Pendirian Perseroan berdasarkan Undang-Undang Perseroan Terbatas. Akta Pernyataan dan Akta Wasiat adalah kehendak sepihak dari Po Guan Cuan, maka tentu berhubungan dengan Pasal 966 BW yang isinya Akta yang isinya menghibahkan suatu barang milik orang lain, bukan miliknya maka Akta Wasiat tersebut tidak dapat dilaksanakan.

Eksepsi yang telah dikabulkan oleh Majelis Hakim Mahkamah Agung sesungguhnya sudah benar mengenai gugatan tidak dapat diterima karena kurang pihak. Sehingga apabila gugatan dikabulkan eksekusi tidak dapat dilaksanakan sehingga tidak dapat menyelesaikan perkara secara tuntas. Selain itu, berdasarkan Pasal 48 UndangUndang Nomor 40 Tahun 2007 tentang Perseroan Terbatas yang selanjutnya disebut Undang-Undang Perseroan Terbatas memang hanya mengenal saham atas nama dan pemegang sahamnya hanya 
Daniel Kuntjoro Budiman: Sengketa Warisan Perusahaan Perorangan Berubah Menjadi...

yang termuat dalam akta pendirian dan susunan pemegang saham. Berdasarkan Pasal 38 KUHD, dan Pasal 7 ayat 1 Undang-Undang Nomor 1 Tahun 1995 tentang Perseroan Terbatas dan Pasal 17 ayat 1 Undang-Undang Nomor 40 Tahun 2007 tentang Perseroan Terbatas, yang menegaskan bagaimana cara pendirian Perseroan Terbatas, yaitu dibuat dengan Akta Otentik atau Akta Notaris. Berdasarkan Pasal 8 ayat 1 UndangUndang Perseroan Terbatas menegaskan, memuat nama lengkap, tempat tinggal dan tanggal lahir pendiri dll. Terbukti tidak tercantum ada nama Go Soe Loet maupun Po Guan Cuan sebagai pemegang saham dalam Akta Pendirian PT Santos Jaya Abadi. Dikuatkan lagi dalam Pasal 43 ayat 1 Undang-Undang Nomor 1 Tahun 1995 jo. Pasal 50 ayat (1) Undang-Undang Nomor 40 Tahun 2007 tentang Perseroan Terbatas, pemegang saham yang sah dalam Perseroan hanya saham yang terdaftar namanya dalam Daftar Pemegang Saham.

PT Santos Jaya Abadi didirikan telah sesuai dengan peraturan perundangundangan Indonesia. Berdasarkan Pasal 37 Kitab Undang-Undang Hukum Dagang, bila perseroan itu tidak bertentangan dengan kesusilaan atau dengan ketertiban umum, dan selain itu tidak ada keberatankeberatan terhadap pendiriannya, maka izinnya diberikan. Dalam hal Perseroan Terbatas telah berdiri dengan tidak ada keberatan-keberatan dari pihak yang berkepentingan maka sesungguhnya Perseroan Terbatas telah berdiri secara sah.
Tetapi yang perlu dibahas adalah modal saham pendirian PT Santos Jaya Abadi yang mempergunakan uang yang seluruhnya berasal dari orang tua. Karena seluruh modal saham pendirian PT Santos Jaya Abadi Soedomo Mergonoto, Indra Boedijono dan Singgih Gunawan telah terbukti berasal dari orang tua maka saham yang dimiliki mereka di PT Santos Jaya Abadi merupakan harta warisan orang tua, yaitu Go Soe Loet dan Po Guan Cuan.

Ternyata tidak seluruh PT Santos Jaya Abadi merupakan warisan Go Soe Loet dan Po Guan Cuan, tapi hanya sebagian. Bagian yang menjadi warisan hanyalah bagian saham yang dimiliki oleh Indra Boedijono, Soedomo Mergonoto dan Singgih Gunawan dalam PT Santos Jaya Abadi.

Gugatan yang diajukan pada Pengadilan Negeri Surabaya pada dasarnya adalah mendalilkan pendirian PT berasal dari uang orang tuanya sehingga termasuk sebagai harta atau boedel waris dari orang tua, yaitu Go Soe Loet dan Po Guan Cuan. Dalam persidangan telah berhasil dibuktikan pendirian PT Santos Jaya Abadi berasal dari uang orang tuanya, sehingga dalam hal demikian sesungguhnya saham-saham yang dimiliki oleh Indra Boedijono, Soedomo Mergonoto, dan Singgih Gunawan adalah harta warisan Go Soe Loet dan Po Guan Cuan. Jadi tidak otomatis harta yang ditinggalkan oleh seseorang yang telah meninggal dunia adalah harta warisan, karenanya harus dibuktikan terlebih dahulu. (Anisitus Amanat, 2000) 
Indra Boedijono dan Soedomo Mergonoto telah mendirikan PT Santos Jaya Abadi, melakukan perbuatan melanggar hukum yaitu melanggar hak Legitime Portie saudara-saudaranya, yaitu ahli-ahli waris orang tuanya. Berdasarkan Pasal 570 BW bahwa hak milik adalah hak menikmati suatu barang secara leluasa dan bebas, asalkan tidak bertentangan dengan undang-undang atau peraturan umum yang ditetapkan oleh kuasa yang berwenang dan asal tidak mengganggu hak-hak orang lain. Mereka telah mendirikan PT Santos Jaya Abadi secara melanggar hukum karena bertentangan dengan undang-undang atau peraturan umum yang dan melanggar hakhak orang lain. Seharusnya saham-saham yang dimiliki Indra Boedijono, Soedomo Mergonoto, dan Singgih Gunawan termasuk sebagai boedel waris Go Soe Loet dan Po Guan Cuan.

Memang benar bahwa Go Soe Loet dan Po Guan Cuan bukan pendiri dari PT Santos Jaya Abadi, namun saat mendirikan PT Santos Jaya Coffee Company terbukti berasal dari uang orang tua maka harta warisan Go Soe Loet dan Po Guan Cuan adalah saham-saham yang dimiliki oleh Indra, Soedomo dan Singgih Gunawan. Oleh karena saham-saham pendirian dimiliki oleh Indra, Soedomo dan Singgih terbukti merupakan harta warisan Go Soe Loet dan Po Guan Cuan, maka merupakan harta warisan yang belum terbagi berdasarkan Pasal 1066 BW. Maka seharusnya saham-saham yang dimiliki oleh Indra Boedijono, Soedomo Mergonoto dan Singgih Gunawan dibagikan kepada 7 ahli waris lainnya sesuai wasiat dengan dilakukan pengurangan untuk memenuhi legitime portie masing-masing ahli waris. Hal ini menunjukkan bahwa menurut BW hukum waris memiliki ciri khas yang menghendaki agar harta peninggalan seorang pewaris secepat mungkin dibagibagi kepada mereka yang berhak atas harta tersebut. (E. Suparman, 2005)

\section{SIMPULAN}

Hasil analisa dapat ditarik kesimpulan bahwa perusahaan kopi bubuk Kapal Api yang merupakan perusahaan perorangan Hap Hoo Tjan diubah menjadi badan hukum PT Santos Jaya Abadi dimiliki oleh Indra Boedijono, Soedomo Mergonoto dan Singgih Gunawan dapat dibenarkan, karena PT Santos Jaya Abadi didirikan pada tahun 1979 telah sesuai dengan Kitab Undang-Undang Hukum Dagang dan kemudian telah ada penyesuaian dengan Undang-Undang Nomor 1 Tahun 1995 dan diperbarui dengan Undang-Undang Nomor 40 Tahun 2007 tentang Perseroan Terbatas. Apalagi Asal usul keuangan pendirian PT Santos Jaya Coffee Company adalah berasal dari perusahaan perorangan Hap Hoo Tjan yang dimiliki oleh Go Soe Loet dan Po Guan Cuan. Terbuktinya keuangan berasal dari Go Soe Loet dan Po Guan Cuan maka PT Santos Jaya Abadi adalah juga milik keluarga. Dengan demikian PT Santos Jaya Abadi tidak lain adalah warisan dari Go Soe Loet dan Po Guan Cuan, sehingga Po Guan Cuan yang mewasiatkan hanya sebatas setengah bagian dari harta bersama dengan tidak boleh melanggar Legitime Portie.

Hendaknya ahli waris lainnya mengajukan gugatan pembagian warisan 
Daniel Kuntjoro Budiman: Sengketa Warisan Perusahaan Perorangan Berubah Menjadi...

Go Soe Loet dan pelaksanaan wasiat Po Guan Cuan yaitu pembagian warisan berupa saham-saham PT Santos Jaya Abadi atas nama Indra Boedijono, Singgih Gunawan dan Soedomo Mergonoto dengan memperhatikan Legitime Portie masing-masing ahli waris.

\section{UCAPAN TERIMAKASIH}

Dalam penyelesaian jurnal ini, saya mengucapkan terima kasih atas segala bimbingan bantuan, kritik, saran serta dukungan kepada Rektor Universitas Surabaya yang telah memberikan kesempatan untuk menjadi bagian dari civitas di akademika Universitas Surabaya, Dekan Fakultas Hukum Universitas Surabaya yang telah memberikan kesempatan dan menyediakan sarana dan prasarana kegiatan perkuliahan di Fakultas Hukum Universitas Surabaya, Kepala Laboratorium Hukum Keperdataan Universitas Surabaya, Ibu Dr. Sylvia Janisriwati, S.H., M.Hum., yang telah menyediakan waktu dan sejak awal memberikan arahan, masukan, kepercayaan serta dukungan terhadap proposal yang saya ajukan sehingga jurnal ini dapat terselesaikan, Dosen Pembimbing saya Prof. Dr. Lanny Kusumawati, Dra., S.H., M.Hum. dan Ibu Sriwati, S.H., M.Hum. yang dengan penuh pengertian dan kesabaran menyediakan tenaga, pikiran, dan waktu di tengah kesibukan dalam memberikan bimbingan, arahan, dan nasihat sehingga jurnal ini dapat saya selesaikan.

\section{DAFTAR PUSTAKA}

Afandi, A. (1986). Hukum Waris Keluarga dan Hukum Pembuktian Menurut
Kitab Undang-Undang Hukum Perdata (bw). In Bina Perkasa.

Anisitus Amanat. (2000). Membagi Warisan Berdasarkan Pasal-Pasal Hukum Perdata BW. Jakarta: PT Raja Grafindo.

Boty, R. (2017). Kekuatan Akta Notaris Dalam Menjamin Hak Keperdataan. Jurnal Cendekia Hukum: Vol.3, No.1, September 2017, 3(1), 14.

Dewi, N. P. Y. K., \& Purwanti, N. P. (2014). Tata Cara Penuntutan Hak Waris oleh Ahli Waris yang Sebelumnya Dinyatakan Hilang Berdasarkan Kitab Undang-Undang Hukum Perdata (KUHPerdata). Bagian Hukum Perdata Fakultas Hukum Universitas Udayana, 4(2).

Emeliana Krisnawati. (2006). No Hukum Waris Menurut Burgerlijk Wetboek $(B W)$. Bandung: CV Utomo.

Isnaini, E. (2014). Hukum Hibah Wasiat Terhadap Anak Angkat Menurut Hukum Perdata. Jurnal Ilmu Sosial Dan Humaniora.

Kamilah, A., \& Aridhayandi, M. R. (2015). Kajian Terhadap Penyelesaian Sengketa Pembagian Harta Warisan atas Tanah Akibat Tidak Dilaksanakannya Wasiat oleh Ahli Waris Dihubungkan dengan Buku II Kitab Undang-Undang Hukum Perdata tentang Benda (Van Zaken). Jurnal Wawasan Hukum, Vol.32, No.1, Februari 2015, 32(1).

Kusumawati, L. (2011). Pengantar Hukum Waris Perdata Barat. Surabaya: Laros.

Mohammad Yasir Fauzi. (2016). Legislasi Hukum Kewarisan di Indonesia. 
Jurnal Pengembangan Masyarakat Islam, 9(2).

Pangemanan, M. M. (2016). Kajian Hukum atas Hak Waris Terhadap Anak Dalam Kandungan Menurut KUHPerdata. Lex Privatum, IV(1).

Pratama, A. P., Syaifuddin, M., \& Elmadiantini, A. A. (2015). Akibat Hukum Wasiat yang Berisi Penunjukkan Ahli Waris dan Hibah Wasiat Menurut Kitab UndangUndang Hukum Perdata. Jurnal Ilmiah Hukum Kenotariatan, 4(2).

PricewaterhouseCoopers. (2014). Survey

Bisnis Keluarga 2014. Retrieved July 22, 2019, from https://www.pwc.com/id/en/publicati ons/assets/indonesia-report-familybusiness-survey-2014.pdf

Prodjodikoro, W. (1986). Hukum Warisan di Indonesia. Bandung: PT Bale Bandung.

R. Santoso Pudjosubroto. (1964). Masalah Hukum Sehari-Hari. Yogyakarta: Hien Hoo Sing.

Satrio. (1998). Hukum Waris tentang Pemisahan Boedel. Bandung: Citra Aditya Bakti.

Suparman, E. (2005). Hukum Waris Indonesia. 2005: Refika Aditama.

Suparman, M. (2005). Hukum Waris Indonesia. Jakarta: Sinar Grafika.

Tamakiran. (1987). Asas-Asas Hukum Waris Menurut Tiga Sistem Hukum. Bandung: Piionir Jaya.

Wahyu Setiadi, \& Sumarto, S. (2014). Pembagian Harta Warisan pada Masyarakat Muslim Desa Sugihan Kecamatan Tengaran Kabupaten
Semarang. Unnes Civic Education Journal, 3(2).

Wattimena, C. N. (2017). Perlindungan Hukum Bagi Ahli Waris yang Belum Dewasa Dalam Perspektif Kitab Undang-Undang Hukum Perdata. 